\title{
THE INTERACTION BETWEEN REGIONAL SCIENCE AND ECONOMICS: AN ECONOMIST'S VIEW
}

\author{
William J.Milne*
}

In this paper, I consider some areas of interaction between regional science and economics. The focus of the paper is what economics has gained from the existence of the discipline of regional science and, perhaps more importantly, what regional scientists should be applying from the economics field and, especially, from recent developments in economics.

To begin, consider what regional science research has offered the economics discipline. Of course, traditionally, concepts have been developed in economics and then applied by regional scientists. However, there are several areas where research in regional science has had an important impact on regional and urban economics, if not on the general field of economics.

First, the fact that regional science is interdisciplinary (combining elements of economics, geography, planning, and operations research, for example) demonstrates to economists who work in the field that they must broaden their analysis. Economists often tend to be narrow in their perspective, typically with strict reliance on the neoclassical paradigm and with restrictive assumptions (for example, constant returns to scale). In fact, when dealing with space, as Krugman (1991) has noted, the interaction of economies of scale with transportation costs is important. Indeed, using relatively recent research from the industrial organization field of economics, we can see that there is a renewed interest in economic geography, which ties in with the extensive regional science literature on industrial location.

Another example is provided by migration analysis. Economists tend to view migration in terms of a human capital model (see Sjaastad 1962) derived, for example, from individual or household utility maximization across space and over time. Geographers who are also regional scientists tend to approach the problem differently through use of the doubly constrained gravity model (many examples of this modelling approach exist, for example, Plane 1984) or spatial interaction models (see Fotheringham and O'Kelly 1989). Yet there has not been a significant effort to explain the differences across these approaches. Time series modelling of aggregate migration flows by economists tends to be econometrical-

*Department of Economics, Vaughan Chair in Regional Economics, University of New Brunswick, Fredericton, New Brunswick. 
ly based and ensures adding-up through cross-equation parameter restrictions (e.g., Greenwood and Hunt 1984 or Foot and Milne 1984) while other methods impose restrictions through matrix identities. However, more recently, emphasis has tumed to the use of micro data sets and, in this regard, as Greenwood et al. (1991) point out, migration research should begin to focus on "spatial choice sets" where a manageable set of destinations is analyzed by the potential migrant. This necessarily requires a broadening of migration research to include results of the work by sociologists and psychologists. In general, the use of micro data sets allows for a more rigorous testing of the human capital model-an area closely related to the field of labor economics.

Second, regional scientists have taken over some fields that economists have researched extensively in the past. An important example of this is input-output analysis. Much of the current research undertaken on this topic is by regional scientists, and this important work is being extended to the area of social accounting matrices (e.g., Batey and Rose 1990). Much of this research will be important to economists working in the field of computable general equilibrium models (see below).

Third, a remarkable contribution has been the way that regional scientists tackle data problems. Examples abound of the innovative methods that were developed by regional scientists. Whether in constructing regional input-output tables, determining the base by location quotient (or some other method) in economic base models, or in constructing regional econometric models, data construction has been an important part of regional science research. While the regional input-output literature likely provides the best example of data construction techniques through its use of nonsurvey techniques (e.g., Richardson 1985), methods like the Kendrick-Jaycox technique of obtaining Gross State Product or the minimum techniques procedure in economic base analysis are also important data construction developments in regional science.

Finally, it is critical to note that some problems are truly regional in nature. The housing market immediately comes to mind. While demographics should play an important role in housing demand, on the national level, these demographic forces are often obscured (as noted, for example, by Mankiw and Weil 1989 or by Poterba 1991). On a regional level, besides the usual demographic effects of age composition of the population, the role of interregional and international migration can have important effects on the demand for housing. In the Canadian context, the fact that most international immigrants locate in one of three major cities (Vancouver, Toronto, or Montreal) has caused substantial shortterm increases in house prices. Interprovincial migration has also had an impact on the housing market, especially in Alberta during and after the energy boom of the early 1980s, where there were first dramatic increases in rents and housing 
prices followed by an equally dramatic decrease after energy prices fell. Furthermore, the dynamics in the rental versus single-dwelling markets associated with migration flows needs to be explored. In general, economists need to be more careful in analyzing truly regional problems in a regional context.

Let me next consider the challenge facing researchers in regional science as a result of the research being undertaken in the economics discipline. In recent years, mainstream economists seem to have rediscovered regional economics. Two examples of this are the papers by Barro and Sala-i-Martin $(1991,1992)$ and Blanchard and Katz (1992). The Barro and Sala-i-Martin papers reconsider the issue of income convergence across states based on a simple, but rigorous, neoclassical growth model. They provide convincing evidence of income convergence across the United States in the sense that states that begin with per capita incomes below the national average tend to grow faster than states that begin with per capita incomes above the national average. Of course, the interesting issue here is how to explain the convergence. Surprisingly, Barro and Sala-i-Martin find that migration, based on a particularly simple functional form, explains only a small part of the convergence. The implied migration function in Blanchard and Katz is also very simple, and they find that "labor mobility . . . appears to be primarily a response to changes in unemployment rates" (Blanchard and Katz $1992,52)$. Both of these results seem to be at odds with published research in regional science journals. Furthermore, neither of these studies reference research undertaken by regional scientists. This reflects the need for regional scientists to publish their research results in more mainstream joumals rather than to focus on the narrow audience of regional science journals.

Also, in this relatively recent literature, the new growth theory as developed, for example, by Romer (1986, 1990), is not taken into account. This new growth theory emphasizes the role of human capital development and its effect on the evolution of steady state per capita income. If there are unobserved differences in steady state incomes across regions, for example, this could be modelled through a time series process. This notion of "drift" in steady state income is consistent with the new growth theory, while convergence of incomes across regions is consistent with neoclassical growth theory. This result suggests that models that incorporate elements of both theories are required, and, perhaps more importantly, this approach permits differences in regional endowments and other characteristics (that affect total factor productivity) to be incorporated into the specification.

Krugman (1991) examines the issue of increasing returns and regional economics through a model that focuses on the long-studied regional science question of firm location. The Krugman theoretical model shows how a coreperiphery pattern of development can occur. Krugman's results, based on the 
theoretical industrial organization literature, show how regions can gain based on the interaction among population size, transportation costs, and economies of scale. Similarly, Porter $(1990,1991)$ notes the importance of clusters of economic activity through a pattem of vertically linked activity-clearly a regional concept.

While this recent work in regional economics is important, it is useful to remind regional scientists of other concepts developed in the economics discipline. First, I offer a plea not to forget theory in empirical work. While some researchers find fault with neoclassical economics and often prefer to be structuralists, the neoclassical model, as long as it is not interpreted too narrowly, provides a convenient starting place for any analysis. An example of the importance of theory in empirical work is provided by research on total factor productivity (e.g., Hulten and Schwab 1984; Moomaw and Williams 1991). In this case, the restrictions required from economic theory are imposed at the estimation stage to generate total factor productivity growth rates that are consistent with theory. The difference in these regional growth rates can then be explained by different regional characteristics-for example, regional differences in public infrastructure, training, education, tax structure, etc. The analysis of total factor productivity growth is preferable to measuring labor productivity growth, and the correct estimation strategy (with appropriate cross-equation restrictions) is crucial in determining the importance of productivity growth in the regional economy.

A relatively new area of research in regional economics is the construction and use of computable general equilibrium models (CGEs) that are regional or, more appropriately, multiregional. Once again, the advantage of this approach is that it models the regional economy within a theoretical framework. Some regional CGEs have been constructed (e.g., Whalley and Trela 1986; Harrigan and McGregor 1989), but they remain in their infancy partly due to data issues and to difficult theoretical problems (for example, the appropriate closure rule). CGEs can be used in the analysis of public finance questions on a regional or interregional basis, can assist in determining the gains that may be achieved through the removal of interregional barriers to trade (in goods, labor, or capital), and have been used to assess the impact of trade liberalization (e.g., Harris and Cox 1984).

In using CGEs to undertake policy analysis, regional scientists must still address a number of interesting questions. Perhaps the most important of these is how to deal with trade among the regions. Very few countries have a multiregional trade flow matrix yet, and as national CGEs have shown, the trade elasticities are critical in determining the effect of policies on the economy. Clearly, given regional scientists' background with input-output analysis, methods of allowing the trade proportions (for both intermediate and final goods) to change can be introduced. One such method may be to allow them to change in response to changes in relative prices. Another important issue to be addressed is the degree 
of mobility of labor and capital across regions. The migration literature has much to say about the impediments to labor migration and, therefore, to the slow adjustment of labor to changes in economic conditions. Incorporation of the results of this literature in multiregional CGEs can assist in our understanding of income convergence across regions.

The field of public finance has a number of implications for regional economics. These concerns typically deal with equity versus efficiency issues. In this regard, an important area of research is whether government policies that transfer money to different regions, for equity reasons, have implications for economic efficiency. As Boadway and Flatters (1982) note, in the Canadian case, there are convincing reasons why an equalization payment scheme is efficient. Furthermore, the role of government programs in eliminating regional economic disparities must be better understood. Some govemment programs-for example, regional development programs and other institutions (such as regionally differentiated unemployment insurance benefits)-may lead to regional inefficiency by slowing the movement of the factors of production to where their returns are the highest. Similarly, the existence of interregional nontariff barriers to trade, which are widespread, can result in slower convergence or may lead to interregional equilibrium wage differentials (see Dickie and Gerking 1987).

Game theory has made important contributions to economic theory, especially in the area of industrial organization (e.g., Kreps 1990). Yet, we have not seen much use of game theory in the area of regional science. One example where game theory may have important implications is its use in industrial location applications. In a zero-sum game, where a firm must choose where to locate across regions, regional governments may try to attract firms through tax concessions. By offering such incentives, a region may benefit if the actions of all other regions are held fixed. However, if other regions also offer tax concessions, which often happens, overall welfare in the nation may decrease through this interregional competition.

There is a desperate need in Canada, and likely in the United States as well, for regional planners to reassess the role of regional development policy. Policies that provide large subsidies for firms to locate in lagging regions have typically not worked. Indeed, as Porter (1991, 377) notes, "Direct subsidies also often result in costly mistakes, as the failed history of many Canadian regional development policies attests." The problem typically arises when decisions about subsidies or other incentives are made for political reasons rather than being based on economic realities as determined by the cost-benefit calculus.

There are strong reasons to believe that an appropriate policy need not be a regional development policy, but rather a policy that ensures that businesses and individuals across the country operate in an environment conducive for physical 
and human capital investment, respectively. Indeed, as Romer (1990) notes, subsidies to capital accumulation (for example, federal government development programs) will have no impact on the steady state growth path. He shows that the level of research in an economy, and hence its rate of growth, will depend on interest rates and human capital development. This research, which is still relatively recent, stresses the need for innovation in business (or increases in total factor productivity), retraining of the labor force, and new firm access to venture capital. These are the critical issues in regional economic development.

Finally, with the current concerns about "competitiveness," regional scientists have something to contribute to this debate whether in reference to regional blocs internationally or to regional economies within a nation. It is important to recognize that competitiveness is actually an issue of productivity growth and, in particular, total factor productivity growth. The regional science discipline can contribute to this discussion through an analysis of the determinants of regional economic growth.

In sum, the interaction between regional science and economics continues to be important. The interdisciplinary nature of regional science has much to offer to formulations used in the narrow perspective often adopted by economists. But perhaps more important, the current research being undertaken in economics has important implications for regional scientists in terms of the directions our discipline should take in the future.

\section{REFERENCES}

Barro, R. J., and X. Sala-i-Martin. "Convergence across States and Regions." Brookings Papers on Economic Activity (1991): 107-181. "Convergence." Journal of Political Economy 100 (1992): 223-251.

Batey, P., and A. Rose. "Extended Input-Output Models: Progress and Potential." International Regional Science Review 13 (1990): 27-49.

Blanchard, O. J., and L. F. Katz. "Regional Evolutions." Brookings Papers on Economic Activity (1992): 1-61.

Boadway, R. W., and F. R. Flatters. Equalization in a Federal State: An Economic Analysis. Ottawa: Economic Council of Canada, 1982.

Dickie, M., and S. Gerking. "Interregional Wage Differentials: An Equilibrium Perspective." Journal of Regional Science 27 (1987): 571-85.

Foot, D. K., and W. J. Milne. "Net Migration Estimation in an Extended Multiregional Gravity Model." Journal of Regional Science 24 (1984): 119-133.

Fotheringham, A. S., and M. E. O'Kelly. Spatial Interaction Models: Formulations and Applications. Dordrecht: Kluwer, 1989. 
Greenwood, M. J., and G. L. Hunt. "Econometrically Accounting for Identities and Restrictions in Models of Interregional Migration." Regional Science and Urban Economics 14 (1984): 113-128.

Greenwood, M. J., P. R. Mueser, D. A. Plane, and A. M. Schlottmann. "New Directions in Migration Research: Perspectives from Some North American Regional Science Disciplines." The Annals of Regional Science 25 (1991): 237-270.

Harrigan, F., and P. G. McGregor. "Neoclassical and Keynesian Perspectives on the Regional Macro-economy: A Computable General Equilibrium Approach." Journal of Regional Science 29 (1989): 555-573.

Harris, R., and D. Cox. Trade, Industrial Policy and Canadian Manufacturing. Toronto: Ontario Economic Council, 1984.

Hulten, C., and R. Schwab. "Regional Productivity Growth in U.S. Manufacturing: 1951-78." American Economic Review 74 (1984): 152-161.

Kreps, D. M. Game Theory and Economic Modelling. Oxford: Clarendon Press, 1990.

Krugman, P. "Increasing Returns and Economic Geography." Journal of Political Economy 99 (1991): 483-499.

Mankiw, N. G., and D. N. Weil. "The Baby Boom, the Baby Bust and the Housing Market." Regional Science and Urban Economics 19 (1989): 235-258.

Moomaw, R. L., and Martin Williams. "Total Factor Productivity Growth in Manufacturing: Further Evidence from the States." Journal of Regional Science 31 (1991): 17-34.

Plane, D. A. "Migration Space: Doubly Constrained Gravity Model Mapping of Relative Interstate Separation." Annals of the Association of American Geographers 74 (1984): 244-256.

Porter, M. E. The Competitive Advantage of Nations. New York: The Free Press, 1990.

Canada at the Crossroads: The Reality for a New Competitive Environment. Ottawa: Business Council on National Issues and Minister of Supply and Services, 1991.

Poterba, J. M. "House Price Dynamics: The Role of Tax Policy and Demography." Brookings Papers on Economic Activity 2 (1991): 143-183.

Richardson, H. W. "Input-Output and Economic Base Multipliers: Looking Backward and Forward." Journal of Regional Science 25 (1985): 607-661.

Romer, P. M. "Increasing Returns and Long Run Growth." Journal of Political Economy 94 (1986): 1002-37.

. "Capital, Labor and Productivity." Brookings Papers on Economic Activity: Microeconomics (1990): 337-367. 
Sjaastad, L. "The Costs and Returns in Human Migration." Journal of Political Economy, Supplement 70 (1962): 80-93.

Whalley, J., and I. Trela. Regional Aspects of Confederation. Toronto: University of Toronto Press, 1986. 